This is the author's final, peer-reviewed manuscript as accepted for publication. The publisher-formatted version may be available through the publisher's web site or your institution's library.

\title{
Spanish-American village anatomy
}

Jeffrey S. Smith

\section{How to cite this manuscript}

If you make reference to this version of the manuscript, use the following information:

Smith, J. S. (1998). Spanish-American village anatomy. Retrieved from http://krex.ksu.edu

\section{Published Version Information}

Citation: Smith, J. S. (1998). Spanish-American village anatomy. Geographical Review, 88(3), 440-443.

Copyright: Copyright $@ 1999$ by the American Geographical Society of New York

Digital Object Identifier (DOI): doi:10.1111/j.1931-0846.1998.tb00118.x

Publisher's Link: http://onlinelibrary.wiley.com/doi/10.1111/j.19310846.1998.tb00118.x/abstract

This item was retrieved from the K-State Research Exchange (K-REx), the institutional repository of Kansas State University. K-REx is available at http://krex.ksu.edu 


\section{Spanish-American Village Anatomy}

Jeffrey S. Smith

For a complete pdf version of this article visit: www.k-state.edu/geography/JSSmith/

More than 45 years ago Dan Stanislawski sought to identify the underlying character of 11 towns in Michoacán, Mexico (Stanislawski 1950). He hypothesized that regional differences in the physical environment would have the greatest impact on shaping the personality of each town. The methodology used by Stanislawski to test his hypothesis relied principally upon plotting the anatomy of each village. He mapped the street pattern, central plaza, government buildings, community church, and commercial activities (crafts, stores, and services). Instead of confirming his original thesis, his fieldwork and reflective analysis revealed that culture and first effective settlement had a more profound influence on a town's character than the physical environment. Despite being almost five decades old, anatomically plotting the land use patterns within a village is applicable today and can still reveal many cultural traits of a community.

My research focuses on how diagnostic features on the landscape in Spanish-American communities bears witness to cultural change. In determining the contemporary cultural composition of Spanish-American-established communities in southern Colorado and New Mexico I employed a similar, albeit 
slightly modified, approach to that of Stanislawski. As I mapped the morphology of each community, I noted its shape (paying particular attention to the road network), the characteristics of local irrigation ditches, the location and denomination of the community church(es), and the extent and qualities of commercial activities. My analysis was based upon examining the anatomical design of over 25 communities throughout southern Colorado and New Mexico.

The literature indicates that traditional Spanish-American settlements tend to have a distinct appearance (Figure 1). Commonly they are linear in shape with the Catholic church providing a focal point, have earthen open-air irrigation ditches that traverse the community bringing water to long-lot croplands, and the commercial activity is usually a solitary family-run store/post office. After inspecting my plots, I concluded that where the Spanish-American culture continues to dominate, the traditional town anatomy is maintained. However, where outside cultural influences, especially Anglo, have made inroads into the community, the settlement's morphology assumes a distinctly different appearance (Figure 2). They tend to become more nodal in shape with numerous side streets. No longer is the Catholic church a focal point for the community; multiple churches (especially Protestant) are scattered throughout the village. Commercial activity is concentrated in an easily defined business district with multiple specialty shops offering a limited variety of goods or services. The surrounding croplands are more commonly watered with cementlined irrigation ditches or increasingly by center-pivot sprinklers. 
One Spanish-American diagnostic feature not captured by plotting a town's anatomy is the Penitente morada (worship house). Penitentes are pious lay brethren who were historically infamous for emulating Christ's suffering during Lenten services. Due to past persecution, the typical morada is inconspicuously located and its nondescript form renders it nearly invisible. To reveal this cultural artifact I augmented my plots with personal interviews. Ironically, despite decades of papal condemnation and strained relations with the Roman Catholic church, the resident Catholic priest proved to be the most fruitful contact introducing me to a key informant within the community. After gaining that person's confidence, I had little difficulty penetrating the brotherhood network. Serendipitously, one elder Hermano invited me to witness an Easter celebration at his local morada in New Mexico. I later discovered that by mentioning that experience to other Penitente brothers as I traveled throughout New Mexico and southern Colorado, my inquiries were met with much less suspicion. In the end I revealed a network of communication that has existed between moradas for generations. This allowed me to determine where active moradas exist and where they have been abandoned due to Anglo-introduced services. The Penitente experience illustrates that, despite Anglo-induced changes, communication between brotherhood chapters continues and the strong sense of community and cultural identity that has existed for decades among the SpanishAmerican population is still alive today.

As Dan Stanislawski learned over 45 years ago, plotting a town's anatomy 
can help identify its cultural identity. My research illustrates that an anatomical understanding of a community can also aid in revealing patterns of cultural change.

\section{References}

Stanislawski, Dan. 1950. The Anatomy of Eleven Towns in Michoacán. Austin: The University of Texas Press. 


\section{Additional Readings}

Campa, Arthur L. 1979. Hispanic Culture in the Southwest. Norman: University of Oklahoma Press.

Carlson, Alvar W. 1990. The Spanish-American Homeland: Four Centuries in New Mexico's Rio Arriba. Baltimore: The Johns Hopkins University Press.

Crawford, Stanley. 1988. Mayordomo: Chronicle of an Acequia in Northern New Mexico. Albuquerque: University of New Mexico Press.

de Borhegyi, Stephan F. 1954. The Evolution of a Landscape. Landscape 4:2430 .

Deutsch, Sarah. 1987. No Separate Refuge: Culture, Class, and Gender on an Anglo-Hispanic Frontier in the American Southwest, 1880-1940. New York: Oxford University Press.

Gritzner, Charles F. 1990. Log Barns of Hispanic New Mexico. Journal of Cultural Geography 10:21-34.

Jackson, John B. 1952. Village Types in the Southwest. Landscape 2:14-19.

Knowlton, Clark S. 1969. Changing Spanish-American Villages of Northern New Mexico. Sociology and Social Research: An International Journal 53:455-474.

Lantis, David W. 1998. Early Spanish Settlement in the San Luis Valley. The San Luis Valley Historian 20:5-32.

Nostrand, Richard L. 1992. The Hispano Homeland. Norman: University of Oklahoma Press.

Nostrand, Richard L. and Lawrence E. Estaville, Jr. 1993. Introduction: The Homeland Concept. Journal of Cultural Geography 13:1-4.

Simmons, Marc. 1969. Settlement Patterns and Village Plans in Colonial New Mexico. Albuquerque: University of New Mexico Press.

Weigle, Marta. 1976. Brothers of Light, Brothers of Blood: The Penitentes of the Southwest. Santa Fe: Ancient City Press.

Woodward, Dorothy. 1935. The Penitentes of New Mexico. New York: Arno Press. 


\section{Figure Captions}

Fig. 1-The anatomy of a traditional Spanish-American settlement.

Fig. 2-The anatomy of a Spanish-American-established settlement that has been modified due to Anglo cultural influences. 


\section{Spanish-American Village Anatomy}

by

Jeffrey S. Smith, Ph.D.

Department of Geography

Arizona State University

Tempe, Arizona 85287

(602) 965-7533

or

1535 N. Horne \#34

Mesa, Arizona 85203

(602) 834-1210

Dr. Smith completed his Ph.D. in geography in April, 1997 at Arizona State University, Tempe, Arizona 85287-0104. 
Jeffrey Smith, Ph.D.

1535 N. Horne \#34

Mesa, Arizona 85203

(602) 834-1210

e-mail:jeffss7@imap2.asu.edu

July 25, 1997

Paul F. Starrs, Editor

The Geographical Review

Department of Geography

Mail Stop 154

University of Nevada, Reno

Reno, Nevada 89557-0048

Dear Paul Starrs,

As per your e-mailed response dated July 3, 1997, enclosed please find my submission to the Geographical Field Notes section of The Geographical Review for your consideration. As you recommended, I have tried to emphasize the field investigations portion of my research thus targeting the piece as a field note rather than a record note.

Any changes deemed necessary can easily be accommodated, including the maps. Additionally, if needed, I will gladly provide a list of "Further Readings". If you have any questions or comments please contact me at the address or phone number listed above.

In keeping with the requirements of the Geographical Review 1) this manuscript is not under review elsewhere; 2) it will not be submitted to any other publication while The Geographical Review considers it; 3) the contents of this manuscript have not been submitted elsewhere; and 4) the text is not under copyright.

Sincerely,

Jeffrey S. Smith 